\title{
Impact of combined action of Neem and Eucalyptus oil volatiles on different stages of Corcyra cephalonica (Lepidoptera: Pyralidae)
}

\section{P. H. Pathak* and Sangita Pandey}

Entomology Laboratory, Department of Zoology, D.D.U., Gorakhpur University, Gorakhpur-273009 (Uttar Pradesh), INDIA *Corresponding author. E-mail: paramhans.pathak@gmail.com

\begin{abstract}
Combined action of neem (Azadiracta indica) and eucalyptus (Eucalyptus sp.) oil volatiles causes a sharp reduction in percent egg hatchability in rice moth, Corcyra cephalonica (Stainton) (Lepidoptera: pyralidae) when freshly laid eggs were exposed to these volatiles for 24 hours. A marked decline in egg output and egg hatchability in reproductive pairs, was observed whose larvae were allowed to develop in a programmed manner in an environment, laden with combined action of selected volumes of neem and eucalyptus oil or when both the sexes of these pyralids, were confined for the prescribed limited period, in such odorous environment. A significant reduction in glycogen, lipid and protein level and an increase in free amino acids was noticed in testes and ovaries of these pyralids, when breeding pairs were exposed to the selected volatiles for a period of six hours only.
\end{abstract}

K eywords: C. cephalonica, Egg hatchability, Reproductive potential, Combined action of Neem and Eucalyptus oils

\section{INTRODUCTION}

The rice moth, Corcyra cephalonica (Stainton) is a major pest of stored grain commodities in the tropics (Piltz, 1977). Azadirachta indica, A. Juss (local name : neem) works as larvicidal, growth regulator, antipupational, repellent and oviposition inhibitor (Malhotra and Gujar, 1984; Pathak and Krishna, 1985;1986;1987; 1991; 1992; Kilonzo,1991; Mittal etal., 1995; Nagpal et al. 1995; Dhar et al.,1996; Batra et al., 1998; Shanker and Solanki, 2000; Nagpal et al., 2001; Moore et al. ,2002). E ucalyptus sp. (Local name: eucalyptus) the leaves yield a strong pungent essential oil, exhibited insecticidal, larvicidal and repellant properties against a number of insects (Kambu et al., 1982; Prakash et al., 1982a, 1982b; Chockalingam et al., 1986; Pathak and Dixit,1988; Sharma et al.,1994).

Information is available pertaining to the effect of specified plant components (Pathak and Krishna, 1985, 1987, 1991, 1992; Ansari and Krishna, 1987; Pathak et al., 1994) on the insect reproductive potential and egg hatchability. However, no reports are available regarding the changes that are likely to occur in the post embryonic development and reproduction in this insect, when exposed to the combined action of volatiles emanating from different sources, during rearing or breeding. Therefore, investigations were carried out to ascertain the impact of combined action of neem (Azadiracta indica) and eucalyptus (Eucalyptus sp.) oil volatiles on different stages of $C$. cephalonic, for a stipulated period. The studies were carried out in terms of the eggs laid and hatchability and embryonic- development, effect on immature stages, effect on mating pairs, and their subsequent impact on biochemical levels of glycogen, lipids, proteins and free- amino acids in the gonads of such individuals.

\section{MATERIALS AND METHODS}

A rich standard culture of Corcyra cephalonica was maintained in the laboratory on coarsely ground Jowar (Sorghum vulgar (L.) Moench) containing 5\% powdered yeast (Mishra and Krishna, 1979). From which the eggs, newly hatched larvae, adult males and females (all individuals $<24 \mathrm{hrs}$ old), were drawn for the investigation. Single - freshly hatched larvae were allowed to develop into adults inside muslin-capped glass vials (20 mm diameter, $50 \mathrm{~mm}$ height), unless otherwise stated, on similar dietary medium. Eucalyptus (Eucalyptus sp.) and neem (Azadiracta indica A. Juss) oils were procured from Gupta and Company (P.) Ltd., Sadar Bazar, Delhi and Baidyanath Neem Ka Taila, Baidyanath Ayurved Bhawan Pvt. Ltd., Naini - Allahabad, respectively.

Eggs exposure to the oils: Freshly laid 100 eggs $(<24$ hours) were arranged singly in a linear fashion on the floor of a glass Petri dish $(10 \mathrm{~cm}$ diameter). Two filter paper discs of $3.5 \mathrm{~cm}$ diameter were kept in another Petri dish of same diameter impregnated with $20,40,80$ or 160 $\mu l$ of neem and eucalyptus oils separately. The experimental setups were kept in a glass chamber of 30 $\mathrm{cm}$ diameter and $13 \mathrm{~cm}$ height from inside. For each experimental regimen five replicates were kept. The impregnated paper discs were removed in the first experiment after 3 hours, in second experiment after 6 hours, in third experiment after 12 hours and in fourth experiment after 24 hours. These eggs were shifted from odorous to normal environment, wherein their hatchability 
was monitored daily.

L arval and adult exposure to the oils- The general layout of the experiments, the methodology adopted to treat the larvae or adults with vapour action of these oils and the parameters chosen to assess their impact on postembryonic development, adult emergence and/or reproductive potential of the pest are outlined by Pathak and Krishna (1991). The present studies involve three types of exposure regimens. Larvae of parents were exposed to the vapours of neem and eucalyptus oil (a) for first 15 days of their lives, (b) from $16^{\text {th }}$ day till $30^{\text {th }}$ day, and (c) continuous till $30^{\text {th }}$ day or new born males or females were exposed to the vapours of selected oils in a programmed manner and then paired with the opposite sex. These pairs were then monitored to determine their reproductive potential in terms of total numbers of egg laid and hatchability.

All tests, performed at $27^{\circ} \mathrm{C} \pm 2{ }^{\circ} \mathrm{C}$ and $85 \pm 5 \% \mathrm{RH}$, were accompanied by appropriately designed controls, wherein the insects were not exposed to the oil volatiles. The data procured from adequately replicated experiments, were then subjected to suitable statistical analysis (Paterson, 1939).

Biochemical studies: Testes and ovaries were excised from laboratory reared unmated males and virgin female individuals, unexposed (control) and exposed to 20,40, 80 or $160 \mu \mathrm{l}$ volume of neem and eucalyptus oil volatiles for 6 hours. The isolating organs were separated from flowed out haemolymph and other adhered visceral materials. These were quickly shifted to separate glass plates and their fresh weight was recorded. Subsequently glycogen levels were estimated according to Anthrone method of Van der Vies (1954). Method of Folch et al. (1957) was followed for the extraction of total lipids and its quantitative measurement was carried out by applying the simple charring method of Marsh and Weinstein (1966). Total protein was estimated according to the method of Lowery et al. (1951) and total free amino acids (FAA) was measured according to the method of Spies (1957).

\section{RESULTS AND DISCUSSION}

When freshly laid eggs of $C$. cephalonica, were exposed to the combined action of neem and eucalyptus oil volatiles, for 3 hours duration, a significant reduction ( $\mathrm{P}$ $<0.05$ or $<0.01$ ) in percent egg hatchability was observed at 40,80 or $160 \mu \mathrm{l}$. However, $20 \mu \mathrm{l}$ volumes had no significant effect, even when exposure period was increased for 6 hours, 12 hours or 24 hours. Also, a drastic decline in percent egg hatchability was observed at 40 , 80 or $160 \mu \mathrm{l}$ volume of oils with different exposure periods (Table 1). Presumably, the volatiles entered into eggs via aeropyles- tiny holes in the chorion connected with the respiration of embryos (Chapman, 1982; Mill, 1985;
Sehnul, 1985), leading to their death and there by non hatchability.

Out of the three types of exposures, 30 days continuous exposure was found to be most effective. The exposure of newly hatched larvae with $20 \mu 1$ of both the oils for the first 15 days and from $16^{\text {th }}$ day till $30^{\text {th }}$ day did not result in marked reduction in egg yield and egg hatchability of breeding pairs metamorphosing from such exposed larvae. While in continuous exposure for 30 days, a significant decline $(\mathrm{P}<0.01)$ in eggs laid / egg hatchability was observed. However, reproductive pairs formed from the adults metamorphosing from larvae exposed to 40, 80 or $160 \mu \mathrm{l}$ of oils, showed a severe reduction $(\mathrm{P}<0.01)$ in egg output and egg hatchability as compared to those recorded for untreated individuals (controls) (Table 2). The results were found to be both time and dose dependent. These observations reflect a "carry over" of the deleterious effect of the volatiles from these oils on the developmental and reproductive activities in the biology of this Pyralid pest (Bhanu,1965; Pathak and Krishna, 1991; Pathak et al., 1994).

When freshly emerged 'fattened' males and females were exposed to the combined action of selected oil volatiles for 3 hours, a pronounced increase $(\mathrm{P}<0.01)$ in the egg output and egg hatchability was noticed at 20 or $40 \mu \mathrm{l}$ volume while, at 80 or $160 \mu \mathrm{l}$ volume, a significant reduction $(\mathrm{P}<0.01)$ in egg output and egg hatchability was noticed. The increase in the exposure period of volatiles to 6 hours revealed quite different results. At 20 $\mu l$ volume, the egg output and hatchability was significantly $(\mathrm{P}<0.01)$ increased, while at 40,80 or $160 \mu 1$ volume a successive significant reduction in egg output and egg hatchability was observed $(\mathrm{P}<0.01)$ (Table 3 ). Treatment of both the sexes to the vapour, emanating

Table 1. Estimates of percent hatchability of eggs laid by C. cephalonica following their programmed exposure to different volumes of oils, due to combined action of Eucalytus and Neem oil volatiles.

\begin{tabular}{lcccc}
\hline $\begin{array}{l}\text { Volume of oils } \\
\text { ( in } \mu \mathrm{l} \text { ) }\end{array}$ & \multicolumn{5}{c}{ Percentage hatchability after exposure } \\
& \multicolumn{5}{c}{ period } \\
\cline { 2 - 5 } 3hrs & $6 \mathrm{hrs}$ & $12 \mathrm{hrs}$ & $24 \mathrm{hrs}$ \\
\hline 0 (Control) & $94.2^{\mathrm{a}}$ & $94.2^{\mathrm{a}}$ & $94.2^{\mathrm{a}}$ & $94.2^{\mathrm{a}}$ \\
20 & $93.8^{\mathrm{a}}$ & $91.8^{\mathrm{ab}}$ & $93.4^{\mathrm{a}} \mathrm{b}$ & $91.6^{\mathrm{a}}$ \\
40 & $91.0^{\mathrm{b}}$ & $91.0^{\mathrm{b}}$ & $91.0^{\mathrm{b}}$ & $85.0^{\mathrm{b}}$ \\
80 & $87.8^{\mathrm{c}}$ & $85.6^{\mathrm{c}}$ & $87.8^{\mathrm{c}}$ & $79.8^{\mathrm{c}}$ \\
160 & $85.0^{\mathrm{d}}$ & $80.0^{\mathrm{d}}$ & $75.8^{\mathrm{d}}$ & $71.2^{\mathrm{d}}$ \\
Mean & 90.36 & 88.52 & 88.44 & 84.36 \\
LSD 5\% & 2.5 & $2.9^{2}$ & 2.9 & 4.1 \\
\multicolumn{1}{c}{$1 \%$} & 3.4 & 3.9 & 3.9 & 5.6 \\
\hline
\end{tabular}

Mean followed by different letters differs significantly with control at $5 \%$ or $1 \%$ by Least Significant Difference (LSD) test. 
Table 2. Estimates of mean eggs laid by C.cephalonica and eggs hatched following their programmed exposure, during their immature stages, to different volumes of Eucalyptus and Neem oil volatiles, during rearing.

\begin{tabular}{|c|c|c|c|c|c|c|c|c|}
\hline \multirow{3}{*}{$\begin{array}{l}\text { Experimental } \\
\text { regimen }\end{array}$} & \multicolumn{8}{|c|}{ Volume of oils (in $\mu$ l) } \\
\hline & \multicolumn{2}{|c|}{20} & \multicolumn{2}{|c|}{40} & \multicolumn{2}{|c|}{80} & \multicolumn{2}{|c|}{160} \\
\hline & $\begin{array}{l}\text { Eggs } \\
\text { laid }\end{array}$ & $\begin{array}{c}\text { Eggs } \\
\text { hatched }\end{array}$ & $\begin{array}{l}\text { Eggs } \\
\text { laid }\end{array}$ & $\begin{array}{c}\text { Eggs } \\
\text { hatched }\end{array}$ & $\begin{array}{l}\text { Eggs } \\
\text { laid }\end{array}$ & $\begin{array}{c}\text { Eggs } \\
\text { hatched }\end{array}$ & $\begin{array}{l}\text { E ggs } \\
\text { laid }\end{array}$ & $\begin{array}{c}\text { Eggs } \\
\text { hatched }\end{array}$ \\
\hline No exposure (Control) & $308.8^{\mathrm{a}}$ & $277.4^{\mathrm{a}}$ & $308.8^{a}$ & $277.4^{\mathrm{a}}$ & $308.8^{\mathrm{a}}$ & $277.4^{\mathrm{a}}$ & $308.8^{a}$ & $277.4^{\mathrm{a}}$ \\
\hline $\begin{array}{l}\text { First } 15 \text { days } \\
\text { Exposure }\end{array}$ & $294.6^{a}$ & $275.8^{a}$ & $268.4^{b}$ & $246.6^{b}$ & $255.6^{b}$ & $235.4^{b}$ & $236.0^{b}$ & $210.8^{b}$ \\
\hline $\begin{array}{l}\text { From } 16^{\text {th }} \text { days for } 15 \\
\text { days after hatching }\end{array}$ & $291.4^{\mathrm{a}}$ & $265.0^{\mathrm{ab}}$ & $258.4^{b}$ & $239.8^{b}$ & $241.2^{b}$ & $206.4^{c}$ & $247.0^{\mathrm{bc}}$ & $151.0^{\mathrm{c}}$ \\
\hline $\begin{array}{l}\text { Continuous exposure } \\
\text { till } 30^{\text {th }} \text { day }\end{array}$ & $268.2^{b}$ & $251.2^{b}$ & $230.2^{c}$ & $192.6^{c}$ & $199.8^{c}$ & $157.4^{\mathrm{d}}$ & $209.4^{\mathrm{c}}$ & $133.4^{\mathrm{c}}$ \\
\hline Mean & 290.7 & 267.3 & $266-4$ & 239.1 & 251.3 & 219.1 & 250.3 & 193.1 \\
\hline LSD $5 \%$ & 17.8 & 17.8 & 19.7 & 16.5 & 20.3 & 18.6 & 33.4 & 26.9 \\
\hline $1 \%$ & 24.5 & 24.5 & 27.1 & 22.7 & 28.0 & 25.7 & 46.1 & 37.0 \\
\hline
\end{tabular}

Mean followed by different letters differs significantly with control at $5 \%$ or $1 \%$ by Least Significant Difference (LSD) test.

from different quantities, increased the moth's egg output and egg hatchability. Presumably, vapour density from low volume of volatiles in the breeding chamber remained at sub - harmful level and thus seemed to have stimulated a favorable role in the insect's over all reproductive potential. The concept of hormoligosis - a term applied to the phenomenon in which many stress agents, including chemicals, at sub harmful proportions, may be helpful to organisms in several ways is implicit in this interpretation (Lucky, 1968).

Our investigations revealed $108.29 \%$ and $110.93 \%$ higher glycogen level in the testes and ovaries of treated C. cephalonica respectively as compared to that in the controls when adult moths were exposed the combined action of $20 \mu \mathrm{l}$ neem and eucalyptus oil volatiles for 6 hours. However, after 6 hours of exposure to 40,80 or 160 $\mu \mathrm{l}$ volume of neem and eucalyptus oil volatiles, glycogen level significantly reduced up to $72.35 \%, 48.38 \%$ or $40.55 \%$ in testes and up to $67.18 \%, 48.43 \%$ or $38.54 \%$ in ovaries as compared to that in the controls (Table 4). The reduction in the level of glycogen in the testes may be due to inhibition of synthesis and / or storage of glycogen in the testicular cells, which may create energy crisis, thereby adversely affecting the spermatogenesis (Upadhyay, 1991). A sharp decline in the glycogen content of ovaries due to combined action of volatiles, presumably, affects the synthesis of glycogen in the oocytes adversely inactivating glycogen synthetase and /or by blocking the passage of raw materials for glycogen synthesis into the oocytes ( Bonhag, 1956; Engle's and Drescher, 1964; Ramamurty, 1968; Upadhyay, 1991).

The studies revealed similar kind of pattern in the levels

Table 3. Mean number of eggs laid and their hatchability in C. cephalonica following their programmed exposure to the different volumes of the combined action of Neem and Eucalyptus oil, during their adult stage for 3 hours or 6 hours, just after emergence.

\begin{tabular}{|c|c|c|c|c|}
\hline \multirow{3}{*}{$\begin{array}{l}\text { Experimental } \\
\text { regimen (oils in } \\
\mu l \text { ) }\end{array}$} & \multicolumn{4}{|c|}{ Time of adult exposure } \\
\hline & \multicolumn{2}{|c|}{3 hours } & \multicolumn{2}{|l|}{6 hours } \\
\hline & $\begin{array}{c}\text { M ean eggs laid } \\
( \pm S E)\end{array}$ & $\begin{array}{c}\text { M ean eggs hatched } \\
( \pm S E)\end{array}$ & $M$ ean eggs laid ( $\pm S E)$ & $\begin{array}{c}\text { M ean eggs hatched } \\
( \pm S E)\end{array}$ \\
\hline 0 (control) & $308.8 \pm 11.95^{\mathrm{a}}$ & $300.6 \pm 14.17^{\mathrm{a}}$ & $308.8 \pm 11.95^{a}$ & $300.6 \pm 14.17^{\mathrm{a}}$ \\
\hline 20 & $380.2 \pm 3.53^{b}$ & $375.0 \pm 3.47^{\mathrm{b}}$ & $367.8 \pm 8.76^{b}$ & $360.2 \pm 9.22^{b}$ \\
\hline 40 & $350.0 \pm 3.52^{\mathrm{c}}$ & $342.0 \pm 3.47^{\mathrm{c}}$ & $259.8 \pm 8.33^{c}$ & $251.2 \pm 8.72^{\mathrm{c}}$ \\
\hline 80 & $259.6 \pm 5.39^{d}$ & $250.6 \pm 5.36^{d}$ & $188.2 \pm 8.25^{\mathrm{d}}$ & $177.4 \pm 6.67^{\mathrm{d}}$ \\
\hline 160 & $200.6 \pm 4.50^{\mathrm{e}}$ & $191.0 \pm 4.84^{\mathrm{e}}$ & $129.4 \pm 8.63^{\mathrm{e}}$ & $113.2 \pm 8.46^{\mathrm{e}}$ \\
\hline Mean & 299.84 & 291.84 & 250.8 & 240.5 \\
\hline $\mathrm{LSD}$ at $5 \%$ & 19.39 & 21.90 & 27.45 & 28.89 \\
\hline LSD at $1 \%$ & 26.45 & 29.87 & 37.44 & 39.40 \\
\hline
\end{tabular}

Mean followed by different letters differs significantly with control at $5 \%$ or $1 \%$ by least significant difference ( LSD ) test. SE $=$ Standard Error. 


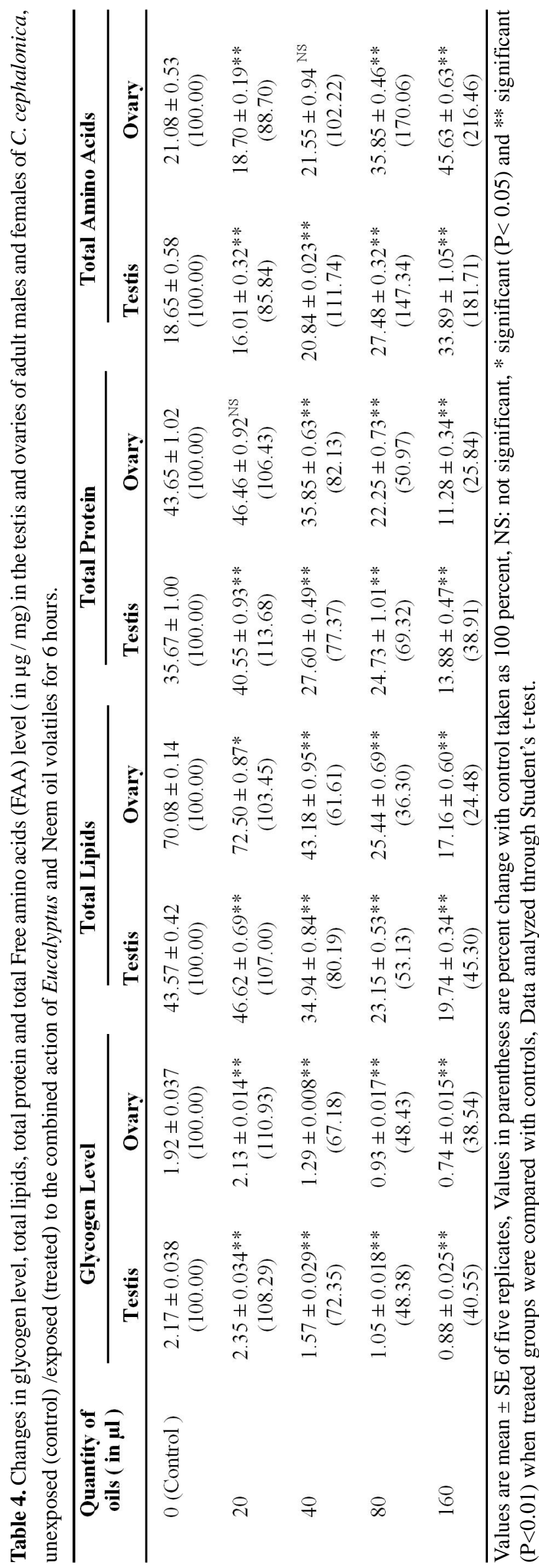

of total lipids as in the glycogen levels. As against controls total lipids rose significantly up to $107.00 \%$ in testes and to $103.5 \%$ in ovaries of C. cephalonica after 6 hours exposure to the combined action of $20 \mu \mathrm{l}$ neem and eucalyptus oil volatiles. Although, after 6 hours of exposure to 40,80 or $160 \mu$ l of neem and eucalyptus oil volatiles, total lipids level significantly decreased to $80.19 \%, 53.13 \%$ or $45.30 \%$ in testes and to $61.61 \%, 36.30 \%$ or $24.48 \%$ in ovaries as compared to the controls (Table 4). Pronounced loss in lipid content in the ovaries of adult females subjected to neem and eucalyptus oil volatiles regimen, can presumably be considered as a reflection of serious dislocation in the physiological operations connected with the movement of lipids which under normal circumstances, occur from fat body to ovary via haemolymph for the purpose of vitellogenesis in the reproductive life of a female insect ( Dean et al., 1985; Keeley, 1985; Kunkel and Nordin, 1985; Mullins, 1985; Bownes, 1986; Raabe,1986; Bhola and Shrivastava, 1986; Shrivastava and Krishna, 1992; Das et al., 1993).

Total protein level was also increased significantly to $113.68 \%$ in testes and to $106.43 \%$ in ovaries of C. cephalonica, after $20 \mu 1$ exposure to combined action of neem and eucalyptus oil volatiles for 6 hours. However, after 6 hours of exposure to 40,80 or $160 \mu \mathrm{l}$ volume of selected volatiles, proteins level was significantly reduced to $77.37 \%, 69.32 \%$ or $38.93 \%$ in testes and up to $82.13 \%$, $50.97 \%$ or $25.84 \%$ in ovaries as compared to the controls (Table 4). The decrease in protein level observed in present investigation may be due to their degradation and possible utilization for metabolic purposes. Decreased protein content might also be attributed to the destruction or necrosis of cells and consequent impairment in protein synthesis machinery. The quantity of protein may also be affected due to impaired incorporation of amino acids into polypeptide chains ( Yadav, 2003).

The levels of total Free amino acids (FAA) however, reduced significantly to $85.84 \%$ in testes up to $88.70 \%$ in ovaries of $\mathrm{C}$. cephalonica after 6 hours exposure to combined action of $20 \mu \mathrm{l}$ neem and eucalyptus oil volatiles. Nevertheless, after 6 hours exposure to 40, 80 or $160 \mu \mathrm{l}$ of neem and eucalyptus oil volatiles, a significant rise in FAA level to $111.74 \%, 147.34 \%$ or $181.71 \%$ was noticed in the testes and non - significantly to $102.22 \%$ and significantly up to $170.06 \%$ or $216.46 \%$ in ovaries, respectively (Table 4). The increased FAA level suggests tissue damage probably due to increased proteolytic activity under volatiles stress. The increase in the level of FAA can also be attributed to the synthesis of amino acids in addition to their elevation by protein hydrolysis. A third possibility for increased FAA level might be due to transamination and animation of keto acids. The accumulation of FAA can also be attributed 
to use of Amino acids and their involvements in the maintenance of an acid - base balance ( Yadav, 2003). Exposure of adult male and female individuals of $C$. cephalonica to the $20 \mu \mathrm{l}$ volume of neem and eucalyptus oil volatiles significantly elevated the glycogen, lipids, proteins while reduced FAA content in the testes and ovaries of these individuals. It seems that the volatiles present in the aroma of these oils have stimulated the physiological mechanism (presumably neuroendocrinally based) associated with glycogen, lipid and protein / FAA synthesis of these tissues - the sites where this activity normally occurs (Das et al. 1993) - resulting in the accumulation of high titre of glycogen, lipid and protein or low titre of FAA in these tissues.

These findings serve as a pointer for considering these botanical products as a potential ingredient, hopefully to be environmentally "friendly" and socially acceptable, for its inclusion in Integrated Pest Management ( IPM ) programme aimed at checking the population build - up of this harmful insect in a problem area. The applied significance of these findings lies in the formulation of appropriate technology from which quantity of these volatiles can be maintained in the population areas, particularly in house - holds.

\section{ACK NOW LEDGEMENTS}

The work is financially supported by University Grants Commission, New Delhi, from Research project No. F. No. $34-414 / 2008$ (SR) provided to PHP.

\section{REFERENCES}

Ansari, A. A. and Krishna, S. S. (1987). Clove oil vapour lowers reproductive efficiency in Corcyra cephalonica (Stainton) (Lepidoptera: Pyralidae) Biol. Bull. of India ,9, 7-10.

Batra, C. P., Mittal, P. K., Adak, T. and Sharma,V. P. (1998).Efficacy of neem-water emulsion against mosquito immatures. Ind. J. Malerioe, 35:15.

Bhanu, D. (1965).The carry over effect of dietary antibiotics in successive generation of the rice - moth, Corcyra cephalonica (Stainton). Zool. Anz. Leipzig. 174:131-133.

Bhola, R. K. and Shrivastava, K.P. (1986). Electrophoretic analysis of the proteins of haemolymph, fat body and ovaries in the red cotton bug, Dysdercus koengii (Heteroptera : Pyrrhocoridae ) during the first egg cycle. In Recent Advances in Insect Physiology, M orphology and E cology (Edited by Pathak, S. C. and Sahai Y. N.), pp. 71-80, Today and Tommorow's Printers and Publishers, New Delhi.

Bonhag, P. F. (1956). The origin and distribution of periodic acid - Schiff positive substance in the oocyte of the earwig, Anisolabis maritima ( Gene ). J. M orph., 99: 433 - 464

Bownes, M. 1986. Expression of the genes coding for vitellogenin (Yolk Protein). Ann. Rev. Entomol., 31 : 507 531.

Chapmann, R. F. (1982). The Insect: Structure and Function Hong Kong, ELBS and Hodder and Stoughton, pp. 919.

Chockalingam, S., Nalina Sundari, M. S. and Vasantha, E. (1986). The use of extract of Eucalyptus in the control of
Spodopter a litura ( Noctuidae : Lepidoptera). J . Adv. Zool. 7: 79-82.

Dass, I. J., Singh, R. P. and Krishna, S. S. (1993). Postembryonic developmental schedule and reproduction of Erias vitella (F.) (Lepidoptera: Noctuidae) under the influence of volatile substances from yellow oleander flowers (Thevetia peruviana (Pers.), Apocynaceae). Phytophaga: 5, 69-75.

Dean, R. L., Collins, J. V. and Locke, M. (1985). Structure of the fat body.In Comprehensive Insect Physiology, Biochemistry and P harmacology,edited by G. A. Kerkut and L. I. Gilbert. Vol. 3, Pergamon Press,Oxford (U. K.). pp. 155-210.

Dhar, R., Dawar, H. Garg, S. S., Basir, F. and Talwar, G. P. (1996). Effect of volatiles from neem and other natural products on genotrophic cycle and oviposition of A nophel es stephensi and A. culiafacies. J . M ed. Entomol., $33: 257$.

Engles, W. And Drescher,W. (1964). Einbau van H3 - DGlucose Wahrend der oogenase bei Apis mellifera (L.). Experiencia, $20: 445-446$.

Folch, J., Lees, M. and Sloane - Stanley, G H. (1957). A Simple method for isolation and purification of total lipids from animal tissues. J ourney of Biological Chemistry, 226: 497 - 507.

Kambu, K., Diphanza, N., Cane, C. Wauters, J. N. and Agenot, L. (1982). Study of chemistry and insecticidal properties of Eucalyptus saligna from Zair. Plant M ed. Phytother. 16:34-38.

Keeley, L. L. (1985). Physiology and biochemistry of fat body. In comprehensive Insect Physiology Biochemistry and Pharmacology ( Edited by Kerkut, G. A. and Gilbert, L. I.), Vol.3, pp. 211 - 248. Pergamon Press, Oxford.

Kilonzo, B. S. (1991). Larvicidal effects of neem (A. indica) on flea in Tanzania. Insect Sci. \& I ts Appl. 12: 699 - 702.

Kunkel J. G. and Nordin J. H. (1985) Yolk protein. In : comprehensive Insect Physiology Biochemistry and Pharmacology ( Edited by Kerkut G. A. and Gilbert, L. I.), Vol. 1, pp. 83 - 111. Pergamon Press, Oxford.

Lowry, O. H., Rosebrough , N. J., Farr, A. L. and Radall, R. J. (1951). Protein measurement with folin phenol reagent. J Biol. Chem.,193: $265-275$.

Lucky, T. D. (1968). Insecticidal hormoligosis. J. Econ Entomol., 61: $7-12$.

Malhotra, K. N. and Gujar, G. T. (1984). Neem as insect growth inhibitor. Natl. Seminar on Neem in Agriculture. IARI N eem Newsletter, 1: 6.

Marsh, J. B. And Weinstein, D.B. (1966). Simple Charring method for determination of lipids, J ournal of Lipid Research 7: 575-57.

Mill, P. J. (1985). Structure and Physiology of the respiratory system In: Comprehensive Insect Physiology Biochemistry and Pharmacology (Edited by Kerkut G. A. and Gilbert L. I.), Vol. 3, pp.517-593. Pergamon Press, Oxford.

Mishra, S. N. and Krishna, S. S. (1979). Influence of some specific time and age related mating schedules on oviposition and egg fertility in Cor cyra cephalonica staint. (Lepidoptera : Galleridae). Entomon, 4: 197-199.

Mittal, P. K., Adak, T. and Sharma, V. P. (1995). Bioefficiency of six neem (A. indica) products against mosquito larvae. Pestic Res. J ., 7: 35

Moore, S. A., Lenglet, A. and Hill, N. (2002). Field evaluation of three plants based insect repellents against malaria vectors in VACA diE2 provience of the Bollivian Amazon. J. Am. 
M osq. Cont. Assoc., 18:107.

Mullins, D. E.(1985). Chemistry and Physiology of hemolymph. In: Comprehensive Insect Physiology Biochemistry and Pharmacology (Edited by Kerkut G. A. and Gilbert L. I.), Vol. 3, pp.355 - 400 .Pergamon Press, Oxford. U. K.

Nagpal, B. N., Srivastava, A. and Sharma, V. P. (2001). Repellent action against neem cream against Anopheles culicifacies and Culex quinquefasciatus. Curr. Sci., 80:1270.

Nagpal, B. N., Srivastava, A., Valecha, N. and Sharma,V.P.(1995). Control of mosquito breeding using wood Scrappings treated with neem oil. Ind. J. Malarioe, 32:64.

Paterson, D. D.1939. Statistical Technique in Agricultural Research M. C. Graw-Hill New York.

Pathak, P. H. and Krishna, S. S. (1985). Neem seed oil a capable ingredient to check rice- moth reproduction. Z. Ang ent. 100: $33-35$.

Pathak, P. H. and Krishna, S. S. (1986). Reproductive eficiency in Earias vitella (F.) (Lepidoptera: Noctuidae) affected by neem oil vapour. Appl. Ent. Zool. 21 (2) 347 - 348.

Pathak, P. H. and Krishna, S. S. (1987). The influence of odours of certain botanical components or an organic solvent dichloromethane during breeding on the reproductive efficiency of Earias vitella (F.) (Lepidoptera: Noctuidae). U ttar Pradesh J. Zool. 7 (2) : 175 - 179.

Pathak, A. K. and Dixit, V. K. (1988). Insecticidal and insect repellent activity of essencial oils of Tridex procumbans and Cythocline lyrate, Fitoterapia, 59: 211-214.

Pathak, P .H. and Krishna, S. S. (1992). Effect of odours of certain plant oils or leaves on the egg Hatchability in C. cephalonica (Stainton) ( Lepidoptera: Pyralidae) Mitt. Zool. M as. Berl. Vol. 68 (1): 139 - 141.

Pathak, P. H. and Krishna (1991). Postembryonic development and reproduction in C. cephalonica (Stainton) (Lepidoptera : Pyralidae ) on exposure to eucalyptus and neem oil volatiles. J . Chemical E cology.17 (12): 2553 - 2558.

Pathak, P. H., Gurusubramanian, G and Krishna, S. S. (1994). Changes in post- embryonic development and reproduction in Corcyra cephalonica (Stainton) (Lepidoptera: Pyralidae) as a function of Eucalyptus and Neem oil vapour action during or on adult. Z. Ang. Zool., 80: 345-352.
Piltz. H. (1977). Corcyra cephalonica (Stainton). In: J . K ranz, H. Schmutterer and W. Koch ( Eds.) Diseases, Pests and Weeds in Tropical Crops. 439 - 440 pp. Verlag Paul Preey, Berlin and Hamburg.

Prakash, A., Pasalu, I. C. and Mathur, K. (1982a). Evaluation of insecticide against Sitotroga cerealella in stored paddy. Oryza, 18: 173 - 174.

Prakash, A., Pasalu, I. C. and Mathur, K. (1982 b). Evaluation of plant products as grain protectants in paddy storage. Indian J. Entomomol. 1: 75-77.

Raabe, M. (1986). Insect Reproduction: Regulation of successive steps. In Advances in Insect P hysiology ( $E$ dited by Evans P. D. and Wigglesworth V. B.), Vol. 19, pp. 29154.

Ramamurty, P. S. (1968). Origin and distribution of the scorpian fly Panorpa communis . . Insect Physiol. 14: 1325 - 1330.

Sehnul, F. (1985). Growth and life cycles. In: Comprehensive Insect Physiology. Biochemistry and Pharmacology. (eds. G. A. Kerkut \& L. T. Gilbert). oxford, Pergamon Press. 2,186.

Shanker, C. and Solanki, K. R.(2000). Botanical Insecticide. A historical perspective. Asian Agri- History, 4 (3): 221- 232.

Sharma, R. N., Deshpandey, S. G, Tungikar, V. B. and Tosheph, M. (1994). Toxicity of natural essencial oils to mosquito Aedes aegypti and Culex fatigans. Geobios, 21: 162- 165.

Shrivastava, S. K. and Krishna S. S. (1992). Eucalyptus oil odour treatment effects on biochemistry of some tissues of female nymphs / adults of Dysdercus koenigii. Insect Sci Applic., 13(1): 145- 149.

Spies, Joseph R. (1957). Colorimetric procedures for amino acids. In: S. P. Colowick and N. O. Kaplan( Eds.). M ethods in Enzymology. 3: 467 - 471 .Academic Press, New York.

Upadhya, B.S. (1991). Effect of thiourea, a chemosterilant on the reproductive biology of the rice moth Corcyra cephalonica (Stainton) (Lepidoptera: Pyralidae). Ph.D. thesis, D. D. U., Gorakhpur University, Gorakhpur.

Van Der Vies, J. (1954). Two methods for the determination of Glycogen in liver. Biochem. J., 57: 410 - 416.

Yadav, R. (2003). Studies on insecticidal properties of commom euphorbious plants against mosquito larvae. Ph. D. Thesis, D.D.U. Gorakhpur University, Gorakhpur. 